\title{
Development of a district level multifaceted first-response strategy to COVID-19 in a resource limited setting in Kerala, India
}

\author{
Raman Swathy Vaman ${ }^{1 *}$, Mathew J. Valamparampil'2, Ramdas A. V. ${ }^{3}$, Manoj A. T.4, \\ Basil Varghese ${ }^{5}$, Flory Joseph ${ }^{6}$
}

\author{
${ }^{1}$ District Program Manager, National Health Mission, Kasaragod, Kerala, India \\ ${ }^{2}$ Assistant Surgeon, District Medical Office, Kasaragod, Kerala, India \\ ${ }^{3}$ District Medical Officer, District Medical Office, Kasaragod, Kerala India \\ ${ }^{4}$ District Surveillance Officer, District Medical Office, Kasaragod, Kerala, India \\ ${ }^{5}$ Junior Resident, Department of Community Medicine, Government Medical College Kannur, Pariyaram, Kerala, \\ India \\ ${ }^{6}$ Epidemiologist, District Medical Office, Kasaragod, Kerala, India
}

Received: 25 June 2020

Revised: 02 August 2020

Accepted: 04 August 2020

*Correspondence:

Dr. Raman Swathy Vaman,

E-mail: ramanvaathapi@gmail.com

Copyright: (c) the author(s), publisher and licensee Medip Academy. This is an open-access article distributed under the terms of the Creative Commons Attribution Non-Commercial License, which permits unrestricted non-commercial use, distribution, and reproduction in any medium, provided the original work is properly cited.

\begin{abstract}
The SARS-CoV-2 pandemic that began in Wuhan in China has spread rapidly with cases currently confirmed in more than 200 countries worldwide. The first case of the outbreak in India was reported on 31st January 2020 in three medical students who returned to Kerala from Wuhan. We report the district level preparedness and response to the first case of COVID-19 infection confirmed in the district of Kasaragod, Kerala. The identification, diagnosis, clinical course and management of the case including surveillance and contact tracing are described. The district level actions before and after the identification of the first case provide a guidance to other resource limited settings regarding the preparedness and mitigation measures to be adopted in times of a pandemic. The evolution of strategies highlights the importance of coordination between district and state health authorities, district administration and line departments; rapid dissemination of health information, disaster preparedness and engagement of the community for surveillance support and home quarantine.
\end{abstract}

Keywords: Covid-19, Emergency preparedness, Low-income population, India

\section{INTRODUCTION}

Several cases of pneumonia of unknown etiology were reported in Wuhan in Hubei province of China from December 8, 2019 onwards. ${ }^{1-4}$ The outbreak was confirmed by the Chinese Center for Disease Control and Prevention from the throat swab of a patient and was found to be caused by a novel corona virus. It was first named by WHO as 2019-nCoV and later renamed to COVID-19.5,6 Coronaviruses $(\mathrm{CoV})$ are enveloped nonsegmented positive- sense RNA viruses found in various mammals and cause illness ranging from the common cold to more severe diseases such as Middle East Respiratory Syndrome and Severe Acute Respiratory Syndrome. WHO declared the 2019-n CoV outbreak as a Public Health Emergency of International Concern (PHEIC) due to the rapid geographic spread across the world. ${ }^{7,8}$ The first three cases in India were reported from the state of Kerala of which one was confirmed in Kasaragod district on February 3, 2020. The aim of this article is to describe the preparedness and response to the first confirmed case in a resource limited district level setting. 


\section{TRIGGER FOR PREPAREDNESS ACTIVITIES}

The first confirmed case in Kasaragod district was a 23year-old male medical student studying at the Wuhan University China. He started his journey on January 22, 2020 and reached Kasaragod on January 27, 2020 using various modes of conveyance. The patient was placed on strict room quarantine at home. He developed mild upper respiratory tract infection on January 30 . He was admitted at the district level first line treatment centre on the following day and was started on empirical therapy with Oseltamivir and azithromycin. A throat swab was sent for RT-PCR evaluation which was subsequently reported as positive for SARS-CoV-2 virus on February 3. Symptoms subsided in the next 3 days and were asymptomatic since day 4 of hospital admission. Four more throat swabs were taken at intervals of 3-4 days for capturing the day of negativity. The fourth and fifth swabs taken on $13^{\text {th }}$ and $14^{\text {th }}$ days of admission were found to be negative. The patient was discharged from the hospital on February 16 as the state discharge criteria of two consecutive negative throat swabs taken 24 hours apart was satisfied. The patient was put on strict room quarantine at home for ensuring a total of 28 days of quarantine. Strict monitoring was done over phone by the field health workers from the designated peripheral health institution of the area. The patient was released from quarantine on February 282020 after completing 28 days in quarantine. ${ }^{9}$

\section{SURVEILLANCE AND CONTACT TRACING}

As the positive case travelled from China to Kasaragod using multiple modalities with multiple halts, contact tracing was cumbersome. Total numbers of primary and secondary contacts were estimated to be 189 and 305 respectively. During the flight and train travels, individuals seated three rows in front and back of the seat of positive case were categorised as high-risk contacts. ${ }^{9}$ The cabin crew members in the airplane and occupants of the exit row seats in train were also added into this group. (Figure1)

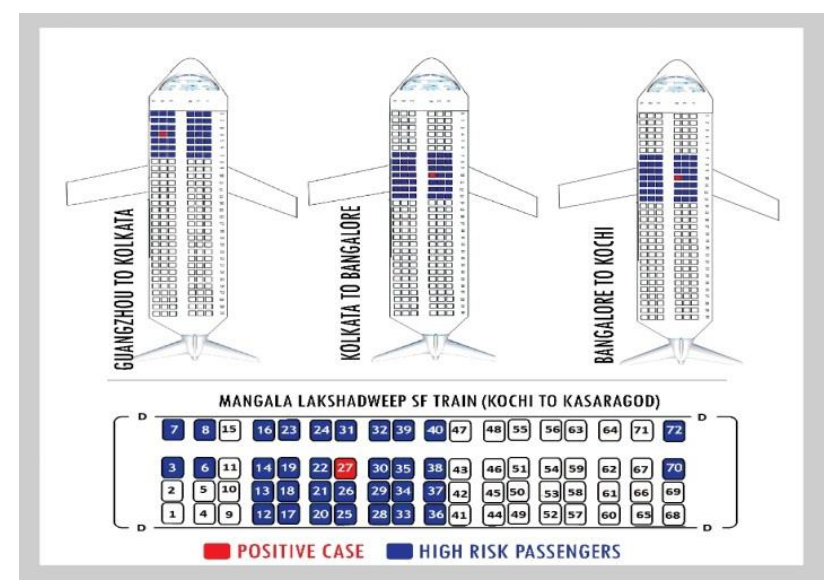

Figure 1: Risk stratification of contacts in flight and train.
Of the 189 primary contacts, 120 were in flight, 25 in train, 26 in hospital, 16 in community and 2 were household contacts. Among the primary contacts in flight and train, 21 were from outside the country while 28 were from outside the state. Details of these primary contacts and secondary contacts outside the state were shared to the concerned district, State and Central Surveillance units for further follow up. (Table 1) ${ }^{9}$

Table 1: Category and number of contacts. ${ }^{9}$

\begin{tabular}{|l|l|}
\hline Category & Number of contacts \\
\hline Primary contacts & 189 \\
\hline $\begin{array}{l}\text { Secondary contacts (inside } \\
\text { district) }\end{array}$ & 305 \\
\hline Outside the district & 37 \\
\hline Outside the State & 37 \\
\hline Outside the Country & 21 \\
\hline $\begin{array}{l}\text { Total actively followed up } \\
\text { from the district }\end{array}$ & 94 \\
\hline Symptomatic contacts & 0 \\
\hline
\end{tabular}

The contacts within the state were telephonically followed up daily from the district corona control cell at Kasaragod for any symptoms. If anybody developed symptoms suggestive of COVID-19 the plan was to isolate them in the facility after taking the swab for RTPCR testing. None of the primary contacts or secondary contacts developed any symptoms during the surveillance period. However, nine asymptomatic high-risk contacts were tested to rule out the chance of occurrence of asymptomatic positive cases and were found to be negative. Additionally, 28 symptomatic out of the 111 people who travelled from the then notifiable countries (China, Hong Kong and Malaysia) were tested as per guidelines and were also found to be negative.

\section{DISTRICT LEVEL PREPAREDNESS AND RESPONSE}

\section{Epidemic preparedness}

On account of the corona virus outbreak in China and the high number of travellers between China and India, the Government of Kerala had alerted all the districts to prepare for the epidemic well in time. A control cell was set up at the office of District Medical Officer (Health) $[\mathrm{DMO}(\mathrm{H})]$ office on $25^{\text {th }}$ of January with a $24 \times 7$ call centre for the general public. The call centre was managed by team of doctors, public health experts and trained counsellors. A Rapid response team (RRT) meeting was conducted with all the medical officers in district and charges were assigned for overseeing various activities in the event of an outbreak. An intersectoral convergence meeting was conducted under the chairmanship of district collector (a civil servant who is the head of district administration and also the district magistrate) and orientation was given to representatives 
from various other departments regarding disease surveillance and control activities.

\section{Infrastructure preparedness}

District of Kasaragod had limited hospital infrastructure even when the private sector is taken into consideration. Isolation facilities were prepared at the two major government hospitals in the district; District Hospital and General Hospital. In the initial phase, isolation rooms with an admission capacity for 100 inpatient admissions were exclusively reserved for the suspects. Parallelly, private institutions were recruited for providing treatment to the COVID patients. Initially, a total of only 6 ventilators were available for a population of 1.3 million people. Twenty more were procured and made functional at the treating hospitals on a war foot basis. In the event of a major outbreak, functional collaborations were established with the public sector tertiary care institutions in the nearby district for management of severe cases. Necessary support was provided for establishment of hand washing facilities at all public places, government and private institutions under the 'Break the Chain' campaign initiated by the Government of Kerala. ${ }^{\mathbf{1 0}}$

\section{Human resource management}

All staffs on non-emergency leave were requested to report back to their respective stations. All the remaining vacancies were filled up on an ad-hoc basis and additional human resources were recruited through the funds available with National Health Mission (NHM) within a period of 1 month. Rational deployment of various categories of staffs were done from peripheral institutions for the proper functioning of designated Covid hospitals without affecting their routine clinical and public health activities. This was achieved by deputing staff from peripheral institutions with no inpatient treatment and with lower outpatient burden. Additional staffs were recruited from institutions catering to regions with lower density of population.

\section{Training and capacity building}

Intensive training and capacity building were started from $28^{\text {th }}$ of January onwards to all category of health staff in both public and private sectors. Additionally, Local Self Government Department (LSGD) members, students, teachers, religious leaders, representatives from general public and other department staffs were provided necessary trainings. More than 2 lakh people were trained in the district over a period of one month (Table 2). Training materials send from the State corona control cell was used for training and capacity building. Zoom video conferencing platform was widely used for training health staff on a regular basis. The training materials/ videos were shared through social media applications like WhatsApp, Facebook etc for wider dissemination. Alternate day trainings were conducted in all schools for improving hand hygiene practices.
Table 2: Various categories of individuals who were trained in Kasaragod district.

\begin{tabular}{|ll|}
\hline Category & $\begin{array}{l}\text { Number of } \\
\text { persons } \\
\text { trained }\end{array}$ \\
\hline Government doctors & 292 \\
\hline Private doctors & 187 \\
\hline Paramedical staff & 531 \\
\hline Attendants & 165 \\
\hline Ambulance drivers - government & 13 \\
\hline Ambulance drivers - private & 38 \\
\hline School children & 179854 \\
\hline School teachers & 6834 \\
\hline Field workers & 438 \\
\hline $\begin{array}{l}\text { Accredited Social Health Activist } \\
\text { (ASHA), Kudmbashree }\end{array}$ & 3796 \\
volunteers & \\
\hline LSGD members & 179 \\
\hline Religious leaders & 28 \\
\hline AYUSH (Non-allopathic) doctors & 94 \\
\hline Line department staffs & 59 \\
\hline Government employees & 206 \\
\hline Community & 19324 \\
\hline Total & 212038 \\
\hline
\end{tabular}

\section{Transportation management}

Two 108-ambulances (ambulances available by dialling '108' and managed across Kerala by the state government) were dissociated from State control and were stationed at District hospital and General Hospital for exclusively transporting the suspected COVID-19 cases. Additionally, 5 ambulances were made available from the private sector. The staffs were all trained for infection prevention and control, vehicle sanitisation and adequate PPEs were made available to them. The entire process was based on World Health Organisation (WHO) protocols for transporting suspected COVID-19 cases.

\section{Logistics management}

Adequate stocks of personal protective equipment, N95 masks, triple layer masks, hand rub solution and viral transport medium were made available in the district. The stock position including buffer stock was monitored daily and lower stocks were replenished by emergency funds made available locally by NHM. The already existing online inventory management system known as the Drug Dispensing and Management System (DDMS) was efficiently used for monitoring the stocks of these supplies on a day to day basis so that a deficit is never reported from any of the institutions.

Information education communication / behaviour change communication (IEC/BCC)

Awareness regarding corona infection, prevention and quarantine were given through print and social media on a regular basis. Notices, pamphlets and voice messages 
both in Malayalam and Kannada languages (2 regional languages commonly used in the district) were also circulated through social Medias such as WhatsApp and Facebook. Videos were circulated among various online medical groups \& forums. Magic shows were arranged at schools for sensitising the students. The social media was scanned daily for any false news or panic creating messages and appropriate legal actions were taken.

\section{Psychological support}

Telephonic facilities were made available for providing psychological support to the persons in quarantine and general public by an experienced psychiatrist and dedicated counsellors posted at the district control centre. Additionally, the dedicated state wide hotline (dialling 1056) for mental health support known as 'DISHA' was publicised extensively in the district.

\section{Actions through Local Self Government Department}

LSGD support was sought for effective implementation of the home quarantine programme. The Panchayat presidents and elected representatives were given briefing on the issue and were requested to provide necessary support to the houses under quarantine. Requirements of food, medicines or any other essential supplies were to be met with the help of dedicated volunteers coordinated by the LSGD. Timely information was to be provided to LSGD regarding the arrival of persons from COVID-19 affected areas so that timely measures could be taken. The role of LSGD was crucial in ensuring appropriate quarantine practices in the community.

\section{Involvement of police personnel}

Additional mechanisms were created for coordination with the local law enforcement authorities. Police also played a major role in ensuring compliance to social distancing and quarantine guidelines. Travel restrictions were to be enforced in high risk areas.

\section{Coordination and monitoring}

For monitoring the situation, $24 \times 7$ control rooms were opened in DMO $(\mathrm{H})$ office and at District Collectorate. Fifteen committees - Surveillance team, Call centre management team, Human resource management team, Training and awareness generation team, Materials management team, Infrastructure management team, Media surveillance team, IEC/BCC and media management team, Documentation team, Private hospital surveillance team, Expert study coordination team, Transportation and ambulance management team, Interdepartmental coordination team, Community level volunteer coordination team and Psychological support team were formed under the leadership of District Collector for coordinating various activities. A district core committee with the following members- District Collector, Additional District Magistrate, District Medical
Officer, District Surveillance Officer, District Programme Manager, District Education and Mass media Officer and District Information Officer were constituted for the overall supervision and consolidation of activities of all other committees. Each team will consolidate the reports in the evening meeting which will be discussed by the district core committee under the chairmanship of District collector at 5 PM every day and bulletin will be prepared and issued to the press media at 6 PM every day. The daily report in the prescribed template will be sent to the State control room every day for state level review and reporting.

\section{CONCLUSION}

The epidemic preparedness activities anticipating the occurrence of a large number of cases started prior to the reporting of the first positive case in the district. The first COVID-19 positive case reported in the Kasaragod district was successfully detected and managed. Extensive contact tracing activities were carried out for finding and testing contacts. The preparedness for managing the epidemic was based at the district level. Infrastructure and human resource were made available in a timely fashion with appropriate financial support from National Health Mission. Logistics and transportation facilities were streamlined for specific covid related activities. Extensive training and IEC activities helped in capacity building and awareness generation. Measures were put in place for ensuring adequate supplies, medicines and psychological support for the people. The district level coordination was done from DMO $(\mathrm{H})$ and District Collector's office. Kasaragod district with its limited resources was able to contain the infection without the emergence of any secondary cases or community spread.

\section{ACKNOWLEDGEMENTS}

Few details given under the headings 'Trigger for preparedness activities' and 'Surveillance \& Contact Tracing' are mentioned in a correspondence made to Indian Journal of Medical Research. (http://www.ijmr.org.in/downloadpdf.asp?id=286317;typ $\mathrm{e}=2$ )

Funding: No funding sources

Conflict of interest: None declared

Ethical approval: Not required

\section{REFERENCES}

1. WHO. Pneumonia of unknown cause - China. WHO. http://www.who.int/csr/don/05-january-2020pneumonia-of-unkown-cause-china/en/ Accessed March 16, 2020.

2. Lu H, Stratton CW, Tang Y-W. Outbreak of pneumonia of unknown etiology in Wuhan, China: The mystery and the miracle. J Med Virol. 2020;92(4):401-2. 
3. David S. Hui, Esam I Azhar, Tariq A. Madani, Francine Ntoumi, Richard Kock, Osman Dar, et al. The continuing 2019-nCoV epidemic threat of novel coronaviruses to global health -The latest 2019 novel coronavirus outbreak in Wuhan, China. Int J Infect Dis. 2020;91:264-6.

4. Chaolin Huang, Yeming Wang, Xingwang Li, Lili Ren, Jianping Zhao, Yi Hu, et al. Clinical features of patients infected with 2019 novel coronavirus in Wuhan, China. The Lancet. 2020;395(10223):497506.

5. WHO. Novel Coronavirus - China. WHO. http://www.who.int/csr/don/12-january-2020-novelcoronavirus-china/en/ .Accessed March 18, 2020.

6. Available at: 20200211-sitrep-22-ncov.pdf. https://www.who.int/docs/defaultsource/coronaviruse/situation-reports/20200211sitrep-22-ncov.pdf?sfvrsn=fb6d49b1_2. Accessed March 16, 2020.

7. Statement on the second meeting of the International Health Regulations (2005) Emergency Committee regarding the outbreak of novel coronavirus (2019nCoV). Available at: https://www.who.int/newsroom/detail/30-01-2020-statement-on-the-secondmeeting-of-the-international-health-regulations- (2005)-emergency-committee-regarding-theoutbreak-of-novel-coronavirus-(2019-ncov). Accessed April 6, 2020.

8. Available at: 20200228-sitrep-39-covid-19.pdf. https://www.who.int/docs/defaultsource/coronaviruse/situation-reports/20200228sitrep-39-covid-19.pdf?sfvrsn=5bbf3e7d_4. Accessed April 19, 2020.

9. Vaman RS, Valamparampil MJ, Ramdas A V, Manoj A T, Varghese B, Joseph F. A confirmed case of COVID-19 among the first three from Kerala, India. Indian J Med Res. 2020;151:493-4.

10. Kerala Launches "Break The Chain" Campaign To Combat Coronavirus. NDTV.com.. Available at: https://www.ndtv.com/kerala-news/kerala-launchesbreak-the-chain-campaign-to-combat-coronavirus2196103. Accessed June 16, 2020.

Cite this article as: Vaman RS, Valamparampil MJ, Ramdas AV, Manoj AT, Varghese B, Joseph F. Development of a district level multifaceted firstresponse strategy to COVID-19 in a resource limited setting in Kerala, India. Int J Community Med Public Health 2020;7:3735-9. 